Bu makaleye atıfta bulunmak için/To cite this article:

SAHIN, U. (2021). How does the Spatial Plane Shade into the Psychological Plane in Alice Munro's Short Story "Train"? An Analysis of Point of View in Fiction from a Different Point of View. Atatürk Üniversitesi Sosyal Bilimler Enstitüsü Dergisi, 25 (4), 1809-1817.

\title{
How does the Spatial Plane Shade into the Psychological Plane in Alice Munro's Short Story "Train"? An Analysis of Point of View in Fiction from a Different Point of View
}

\author{
Ufuk ŞAHIN ${ }^{(*)}$
}

\begin{abstract}
Boris Uspensky, in his A Poetics of Composition (1973), offered a model for the study of point of view in fiction. His model was later revised and refined by British linguist Roger Fowler in his Linguistic Criticism (1986). The Fowler-Uspensky model encompasses four planes: the ideological plane, the temporal plane, the spatial plane, and the psychological plane. In his Stylistics, Paul Simpson also avers that most writers prefer to construct a spatial perspective that shifts "almost seamlessly into the cognitive field of a character." (2004: 80) One conspicuous example of this last case is a short story called "Train" written by Canadian writer Alice Munro. Thus, by using various stylistic tools such as deixis, techniques of speech and thought presentation, and transitivity, the overarching aim of this study is to analyze how the point of view on the spatial plane jells into the psychological plane in "Train".
\end{abstract}

Keywords: Munro, Jackson, Belle, point of view, the spatial plane, the psychological plane.

\section{Alice Munro'nun Kısa Öyküsü “Tren”de Uzamsal Düzlem Psikolojik Düzleme Nasıl Dönüşür? Farklı Bir Bakış Açısından Kurmacada Bakış Açısının İncelenmesi}

Öz: Boris Uspensky, A Poetics of Composition (1973) adlı eserinde, kurmacada bakış açısının incelenmesi için bir model önerdi. Onun bu modeli daha sonra Ingiliz dilbilimci Roger Fowler tarafindan Linguistic Criticism (1986) adlı eserinde gözden geçirilip gelişstirildi. Fowler-Uspensky modeli dört düzlemi kapsar: ideolojik düzlem, zamansal düzlem, uzamsal düzlem ve psikolojik düzlem. Paul Simpson, Stylistics adll eserinde, çoğu yazarın "neredeyse sorunsuz bir şekilde bir karakterin bilişsel alanına" dönüşen uzamsal bir baklş açısı oluşturmayı tercih ettiğini söyler. (2004: 80) Bu son durumun göze çarpan bir örneği, Kanadal yazar Alice Munro tarafindan yazılan "Tren" adlı kısa öyküdür. Bu nedenle, bu çalışmanın genel amacı, gösterim, konuşma ve düşünce sunumu teknikleri ve geçişlilik gibi çeşitli biçem araçlarını kullanarak, "Tren” de uzamsal düzlemdeki bakış açısının psikolojik düzleme nasıl dönüştügüünü incelemektir.

Anahtar Kelimeler: Munro, Jackson, Belle, baklş açısı, uzamsal düzlem, psikolojik düzlem.

Makale Geliş Tarihi: 20.09.2021

Makale Kabul Tarihi: 29.12.2021

DOI: 10.53487/ataunisosbil.998001

\footnotetext{
*) Dr. Öğr. Üyesi, Atatürk Üniversitesi Edebiyat Fakültesi İngiliz Dili ve Edebiyatı Bölümü (eposta: ufuk.sahin@atauni.edu.tr) (D) ORCID ID. https://orcid.org/ 0000-0001-5268-756X

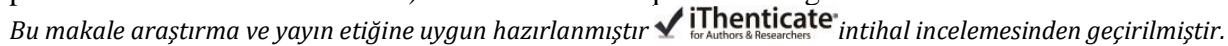




\section{Introduction}

In his A Poetics of Composition (1973), the Russian linguist, philologist, and narratologist Boris Uspensky proposed a model for the study of point of view in fiction. His model was later revised and refined by British linguist Roger Fowler in his Linguistic Criticism (1986: 127-46). There are four components identified by the Fowler-Uspensky model of point of view:

- point of view on the ideological plane

- point of view on the temporal plane

- point of view on the spatial plane

- point of view on the psychological plane

According to Uspensky, the ideological or evaluative plane is the most basic aspect of point of view. He reveals the characteristics of this first category as follows:

This point of view, either concealed or openly acknowledged, may belong to the author himself; or it may be the normative system of the narrator, as distinct from that of the author (and perhaps in conflict with the author's norm); or it may belong to one of the characters (1973: 8).

Likewise, Fowler views the ideological plane as a fundamental category and defines it as "point of view on the plane of ideology in a narrative text, we mean the set of values, or belief system, communicated by the language of the text" (Fowler, 1986: 130).

The point of view on the temporal plane, as the name implies:

[...] refers to the impression which a reader gains of events moving rapidly or slowly, in a continuous chain or isolated segments; it includes also disruptions of the 'natural' flow of time, by for example flashbacks, previsions or the interweaving of stories which concern different timespheres (Fowler, 1986: 127).

In his seminal book Stylistics (2004), Paul Simpson briefly explains the point of view on the temporal plane as a category that is about how relationships of time are signalled in a narrative, and underlines that it encompasses a whole series of stylistic techniques such as repetition, flashback, and flashforward. He compares the third category in the Fowler-Uspensky model (i.e. spatial point of view) to the narrative 'camera angle' (2004: 79). In addition, in his Language, Ideology and Point of View, he states that in constructing the spatial point of view, writers employ some linguistic components such as deixis (deictic verbs, pronouns, and adverbs) supplemented by the category of locative expressions, phrases governed by prepositions denoting place and direction and that function to identify the position of people and objects relative to the speaking or perceiving source (1993: 13).

As for the point of view on the psychological plane, it refers to the ways in which narrative events are mediated through the consciousness (thoughts, senses, and feelings) 
How does the Spatial Plane Shade into the Psychological Plane in Alice Munro's Short Story "Train"? An Analysis of Point of View in Fiction from a Different Point of View

of the narrator or reflector (Uspensky, 1973: 81, Simpson, 2004: 79), and to "the various kinds of discourse associated with different relationships between author and character." (Fowler, 1986: 134).

Special mention should be made here that Simpson tellingly underlines that "spatial perspective shifts almost seamlessly into the cognitive field of a character is an extremely common progression in prose fiction" (2004: 80).

One particularly pertinent example is a short story called "Train" written by Canadian writer Alice Munro who won the Man Booker International Prize in 2009 and was rewarded the Nobel Prize in Literature in 2013. It tells the story of two people with traumatic pasts: Jackson and Belle, whose chance encounter leads to a shared life for quite some time. (for the complete summary, see Appendix)

With the help of various stylistic tools such as deixis, techniques of speech and thought presentation, transitivity, and verba sentiendi, this study thus aims to analyze the point of view development on the spatial and psychological planes in Alice Munro's "Train". Since the story offers plenty of examples, I will make do with particular examples in order not to fall into repetition, and since the fourth example spans more than two pages, I will give its first and the last sentences for the sake of saving space.

\section{Analysis of Point of View on the Spatial and the Psychological Planes}

According to Uspensky, there are cases where "the authorial point of view relies on an individual consciousness (or perception)" (1973: 81). In the same vein, Fowler, while explaining the psychological point of view (also called 'perceptual' point of view), makes a distinction between internal and external perspective, and he explains "internal" narration as:

[...] 'internal' narration is, then, narration from a point of view within a character's consciousness, manifesting his or her feelings about and evaluations of the events and characters of the story (which I shall call type A); or from the point of view of someone who is not a participating character but who has knowledge of the feelings of the characters-the so-called 'omniscient' author (type B) (1986: 135).

Following Fowler's explanations, Munro's text has the characteristics of internal narration: there is an omniscient narrator, and this narrator, in the best part of the story, conveys to readers what is going on in the protagonist Jackson's head, giving an account of his feelings, perceptions, thoughts, and knowledge.

The first example that depicts that Jackson is clearly the reflector of fiction appears at the very beginning of the story:

This is a slow train anyway, and it has slowed some more for the curve.

Jackson is the only passenger left, and the next stop is about twenty miles 
ahead. Then the stop at Ripley, then Kincardine and the lake. He is in luck and it's not to be wasted. Already he has taken his ticket stub out of its overhead notch.

He heaves his bag, and sees it land just nicely, in between the rails. No choice now - the train's not going to get any slower.

He takes his chance. A young man in good shape, agile as he'll ever be. But the leap, the landing, disappoints him. He's stiffer than he'd thought, the stillness pitches him forward, his palms come down hard on the gravel between the ties, he's scraped the skin. Nerves.

The train is out of sight; he hears it putting on a bit of speed, clear of the curve. He spits on his hurting hands, getting the gravel out. Then picks up his bag and starts walking back in the direction he has just covered on the train. If he followed the train he would show up at the station there well after dark. He'd still be able to complain that he'd fallen asleep and wakened all mixed up, thinking he'd slept through his stop when he hadn't, jumped off all confused, then had to walk.

He would have been believed. Coming home from so far away, from Germany and the war, he could have got mixed up in his head. It's not too late, he would be where he was supposed to be before midnight (Munro, 2013: 175-176).

The list of train stations in the first paragraph implies that the information is not provided by the narrator for readers' benefit but by Jackson, who knows the names of the stations by heart, and he is more likely rehearsing them in his mind. So, the point of view shot presents us what Jackson sees or perceives, and his viewing position is established with deictic markers ${ }^{1}$ : adjuncts which express location and spatial relationship such as "he has taken his ticket stub out of its overhead notch", "in between the rails", "the stillness pitches him forward", "his palms come down hard on the gravel between the ties", "The train is out of sight", "Then picks up his bag", "walking back in the direction he has just covered on the train", "Coming home from so far away, from Germany and the war", and "before midnight".

However, Munro is not only satisfied with creating a spatial perspective here but also switches to Jackson's psychological perspective. The sequence beginning with "If he followed the train he would show up at the station there well after dark", for example, points a shift into the conscious thought processes of Jackson. His thoughts are tracked utilizing Free Indirect Thought (referred to as FIT from now on), which also gives the impression of both Jackson and the narrator speaking or thinking simultaneously through

\footnotetext{
${ }^{1}$ deixis; deictic; deictic shift theory (DST) (1) From the Gk 'pointing' or 'showing', deixis in linguistics refers generally to all those universal features of language which orientate or 'anchor' our utterances in the context of proximity of space (here v. there; this v. that), and of time (now v. then), relative to the speaker's viewpoint. (Wales, 2011: 105)
} 
How does the Spatial Plane Shade into the Psychological Plane in Alice Munro's Short Story "Train"? An Analysis of Point of View in Fiction from a Different Point of View

a kind of dual voice. ${ }^{2}$ In addition, the evaluative expression "This is a slow train anyway, and it has slowed some more for the curve." can be attributed to Jackson, which also makes the example in question fits perfectly into Fowler's type A and B.

Moreover, Munro prefers to reflect the cognitive field of Jackson via what Uspensky (1973: 85) calls verba sentiendi, another remarkable linguistic marker in Fowler's type A and B, to denote thoughts, feelings, and perceptions, as embodied in mental processes in Halliday's transitivity model ${ }^{3}$, and uses verbs such as "think", "see", "disappoint", "confuse", and "hear".

So, what happens in this example is that spatial perspective shades into a psychological perspective: Places or actions are focalised almost entirely from Jackson's point of view, and the slip from his role as a reflector or perceiving source for spatial viewpoint into his role as a conscious thinker is relatively undetectable and, to a certain degree, is managed through particular devices employed for representing his thoughts and evaluations. As Simpson indicated, this enables us to subsume the spatial point of view into the broader category of psychological point of view (2004: 79).

The second example covers the period when Jackson and Belle were in a hospital in Toronto to get a lump on Belle removed:

The woman on the bed had not let up on her rhythmical groaning all through this. Jackson felt as if that refrain had entered into his head.

He heard the nurse's squishy shoes in the hall and hoped they would enter this room. They did.

The nurse said that she had to give Belle her sleepy-time pill. He was afraid she would tell him to kiss her good night. He had noticed that a lot of kissing went on in the hospital. He was glad when he stood up that there was no mention of it (Munro, 2013: 198).

\footnotetext{
${ }^{2}$ Fowler indicates that "The difference between type A (internal and wholly sucjective) and type $\mathrm{B}$ (internal but allowing an authorial phrasing of the character's feelings) provides the basis for an important style which throws types A and B into what, [...] I called an implicitly dialogic relationship. This style is free indirect discourse (FID): internal perspective in which the character's subjective feelings, given in type A narration transformed into third person, are interwoven with and framed by the author's account of the character's inner state (type B)." (1986: 138, emphasis in original).

${ }^{3}$ Paul Simpson explains the system of transitivity as "the way meanings are encoded in the clause and to the way different types of process are represented in language." (2004: 22). In the transitivity model, there are six key components of processes, one of which is mental processes. These processes of sensing "inhabit and reflect the world of consciousness, and involve cognition (encoded in verbs such as 'thinking' or 'wondering'), reaction (as in 'liking' or 'hating') and perception (as in 'seeing' or 'hearing')." (Simpson, 2004: 23).
} 
Although the narrator intervenes with Indirect Speech ("The nurse said that she had to give Belle her sleepy-time pill."), the extract is rich in deictic markers of space such as "on the bed", "entered into his head", "enter this room", and "stood up" to refer to the viewing position assumed by Jackson, and verba sentiendi such as "feel", "hear", "hope", "notice", and "to be glad" to manifest his thoughts, feelings, and perceptions. In addition, the expression "the nurse's squishy shoes" implies what Jackson very likely evaluates, not the narrator. So, Jackson's spatial viewpoint again jells into his psychological viewpoint.

Another example is when Jackson decides to walk around the city:

He woke up early, and decided to take a walk before breakfast. He had slept all right but told himself he ought to take a break from the hospital air. It wasn't that he was worried so much by the change in Belle. He thought it was possible or even probable that she would get back to normal, either today or in a couple more days. She might not even remember the story she had told him. Which would be a blessing (Munro, 2013: 199).

This passage also harbours the deictic markers such as "woke up early", "before breakfast", and "either today or in a couple more days". After presenting Jackson's spatial viewpoint, Munro again moves onto his psychological viewpoint by using FIT: "She might not even remember the story she had told him.", and "Which would be a blessing", and verba sentiendi: "decided to take a walk", "but told himself he ought to take a break from the hospital air", "It wasn't that he was worried so much by the change in Belle.", and "He thought it was possible or even probable that she would get back to normal, either today or in a couple more days." to reflect the cognitive field of Jackson.

Suffice it to say here that, starting from the very beginning of this example, Munro uses both locative expressions and other deictic elements and elements that demonstrate Jackson's psychological perspective within the same sentences. It provides Munro's text with an interwoven nature of the spatial and psychological planes. Thus, the spatial and psychological perspectives do not need to appear in succession, but they can also nest together.

Immediately after, Jackson starts to mirror what he sees and thinks while wandering around the city. In the sequence beginning with "The sun was well up, as you could expect at this time of year, and the buses and streetcars were already pretty full.", and ending with "He wouldn't have said he was curious about any of this, more that he was just waiting for the inevitable turn he had been expecting, to take him back to where he'd come from. The man who had come out of the building walked over and asked if he was in a hurry." (Munro, 2013: 199-201), the type of point of view development also proves that Jackson's spatial perspective and psychological perspective are interpenetrating each other.

To achieve this, Munro starts off with using some deictic markers that denote location to signal how reflector Jackson is situated in physical space and how other things or people are positioned relative to him. Examples include: "walked south", "turned west 
How does the Spatial Plane Shade into the Psychological Plane in Alice Munro's Short Story "Train"? An Analysis of Point of View in Fiction from a Different Point of View

", "onto Dundas Street", "after a while", "in the Chinatown", "out of the way", "went into a restaurant", "turn around", "retrace his steps", "heading South", "turn west", "in front of a doughnut shop", "ran into a small crowd of people", "backed right up on the sidewalk", "through the doughnut shop", "through the main door of the building", "on its main floor", and "stood there", and then, switches to Jackson's psychological perspective with verba sentiendi including "feel", "intend", "see", "hear", and FIT with the sentence "He wouldn't have said he was curious about any of this, more that he was just waiting for the inevitable turn he had been expecting, to take him back to where he'd come from."

The last example embraces the time after Jackson abandons Belle in the hospital and when he becomes the superintendent of a five-story apartment with a predominantly elderly population:

On a hot summer day Jackson had the double back doors, the delivery doors, open, to let in what air he could while he worked at varnishing a table. It was a pretty table he'd got for nothing because its polish was all worn away. He thought it would look nice in the entryway, to put the mail on.

He was able to be out of the office because the owner was in there checking some rents.

There was a light touch on the front doorbell. Jackson was ready to haul himself up, cleaning his brush, because he thought the owner in the midst of figures might not care to be disturbed. But it was all right, he heard the door being opened, a woman's voice. A voice on the edge of exhaustion, yet able to maintain something of its charm, its absolute assurance that whatever it said would win over anybody who came within listening range (Munro, 2013: 205).

Once Jackson's spatial viewpoint has been established ("Jackson had the double back doors, the delivery doors, open, to let in what air he could while he worked at varnishing a table. It was a pretty table he'd got for nothing because its polish was all worn away."), Munro once again moves on to the next step to establish his psychological viewpoint.

Keeping her same attitude, she adopts the Free Indirect Discourse ("whatever it said would win over anybody who came within listening range."), and verba sentiendi ("think"). She also receives support from evaluative expressions "pretty table" and "a voice on the edge of exhaustion, yet able to maintain something of its charm" and from the interjection "but it was all right" to push this example away from the narrator towards Jackson. 


\section{Conclusion}

As all these brief analyses indicate, the examples from Alice Munro's "Train" where the character Jackson acted as a reflector, as their context and content imply, illustrated well how locative expressions and other deictic markers work together to construct a point of view on the spatial plane. In addition to those indicators of physical viewpoint, Munro adopts some other stylistic markers such as the technique of FIT by which she invites readers to immerse themselves unreservedly in Jackson's perceptions, thoughts, and feelings, verba sentiendi, and evaluative expressions to change his role from a reflector for the spatial viewpoint into a conscious thinker to construct a point of view on the psychological plane.

The interplay between the spatial and psychological point of view via FIT also enables Munro to blend Jackson's and the narrator's thoughts smoothly, therefore, to give the impression that while Jackson is perceiving what happens around him or thinking about them, the narrator simultaneously conveys his perceptions or thoughts to readers.

\section{References}

Fowler, R. (1986). Linguistic Criticism. Oxford University Press.

Munro, A. (2013). “Train”, In Dear Life. pp. 175-216. Vintage Books. Simpson, P. (1993). Language, Ideology and Point of View. Routledge.

Simpson, P. (2004). Stylistics, a resource bookfor students. Routledge. Taylor \& Francis Group.

Uspensky, B. (1973). A Poetics of Composition. trans. V. Zavarin and S. Wittig. University of California Press, Berkeley. Available at: https://books.google.com.tr/books?id=f7cVTsw0efkC\&printsec=frontcover\&hl=tr $\&$ source $=$ gbs_ge_summary_r $\&$ cad $=0 \# \mathrm{v}=$ onepage $\& \mathrm{q}=\mathrm{verba} \% 20$ sentiendi $\& \mathrm{f}=$ false. (accessed 10 April 2021).

Wales, K. (2011). A Dictionary of Stylistics. Third Edition. Pearson Education Limited.

\section{APPENDIX}

\section{SUMMARY OF THE SHORT STORY "TRAIN"}

In the beginning, the main character (reflector) Jackson, who has recently returned to Ontario from World War II, jumps off a moving train. While walking, he encounters Belle, who is searching for her cow. Belle recognizes him as a soldier and invites him for breakfast.

After her mother has died, Belle has to take care of the farm. Therefore, the farm needs maintenance. Realizing this, Jackson first offers to fix her horse trough and then starts improving the farm. Although he intends to leave the farm in a short time, he cannot realize how much time has passed while busy with the farm. 
How does the Spatial Plane Shade into the Psychological Plane in Alice Munro's Short Story "Train"? An Analysis of Point of View in Fiction from a Different Point of View

One day Belle and Jackson take a trip to Toronto to get a lump on Belle removed. Since her condition is serious, she has to remain at the hospital for a while. Under the influence of medication, she recounts a traumatic memory to Jackson. When Jackson hears that her father intentionally walked into the bathroom while taking a bath, he feels uncomfortable.

The next day Jackson goes out for a walk and hopes that Belle will not remember their conversation. While walking around the city, he sees an ambulance in front of a building. The owner approaches him and asks to watch the building while going to the hospital with the superintendent and caretaker, who then dies. Since Jackson does not want to go back to Belle, he agrees to be the new superintendent and caretaker of this five-story apartment with a predominantly elderly population. One day, he reads in the paper that Belle has died.

Then a woman named Ileane comes looking for her daughter, who has abandoned her residence at the building. Jackson remembers her from high school. Once when Jackson was on leave, they attempted sex, but it did not go well. He tried again with a prostitute, but that did not go well either. It made him stop making marriage plans with Ileane and leave on a train. He did not see her again until she came to look for her daughter. 